\title{
Synthesis of Some New Acetanilide Derivatives as COX Inhibitors and Assessment of Analgesic/ Anti-Inflammatory Activities
}

\author{
RAJIB KUMAR SINGH ${ }^{1,2}$, ARVIND KUMAR ${ }^{1}$ and ARUN K. MISHRA ${ }^{1 *}$ \\ ${ }^{1}$ Central Facility of Instrumentation, Faculty of Parmacy, IFTM University, Moradabad 244001, \\ Uttar Pradesh, India. \\ 2Pharmaceutical Chemistry Laboratory, Shakti College of Pharmacy, Balrampur, 271215, \\ Uttar Pradesh. \\ ${ }^{*}$ Corresponding author E-mail: arun_azam@rediffmail.com
}

http://dx.doi.org/10.13005/ojc/370629

(Received: July 13, 2021; Accepted: December 02, 2021)

\begin{abstract}
The purpose of the present research was to synthesize a new series of acetanilide derivatives that would have analgesic and anti-inflammatory properties in laboratory animals (rats). IR spectroscopy, ${ }^{1} \mathrm{HNMR}$ spectroscopy and Mass spectroscopy were used to confirm the structures of freshly synthesised compounds. The goal of the computer analysis of synthesized compounds was to see how similar they were in terms of physicochemical properties. For this, physiochemical parameters were calculated. The result suggested the reasonable physiochemical similarity with diclofenac sodium and Indomethacin. Molecular docking studies showed that the all the test compounds perfectly docked with COX-2 enzyme with all the drug-likeness characteristics. Before start of In-vivo evaluation, In vitro cyclooxygenase (COX) inhibition assays was performed with an aim to evaluate the compounds against the protein target COX-2 which would exhibit their inhibitory activity. The test compounds (C1-C6) were subjected to analgesic activity evaluation by Eddy's hot plate method and anti-inflammatory activity evaluation by Carageenan induced edema method respectively. Compound C6 [Methyl 2-(2-oxo-2-(p-tolylamino)ethoxy)benzoate] showed highest anti-inflammatory response $(61.36 \%)$ at $120 \mathrm{~m}$, which was quite analogous with the positive control. The response of promising compounds $\mathrm{C} 5$ [2-phenoxy-N-(o-tolyl)acetamide] showed the highest analgesic action. The result concluded that out of all the synthesized compounds, compound $\mathrm{C} 5$ and $\mathrm{C} 6$ could be used as promising new lead molecules to treat pain and inflammation respectively.
\end{abstract}

Keywords: Acetanilide, Phenoxyacetanilide, NSAID, Anti-inflammatory, Analgesic, Structure-activity relationships.

\section{INTRODUCTION}

Inflammation is the reaction of immune system towards damaging stimuli such as pathogens, damaged cells, poisonous substances, or irradiation and anti-inflammatory agents works by removing the harmful stimuli and starts the healing process ${ }^{1,2}$. As a result, inflammation is an important defence mechanism for healthy cells. Inflammation can induce tissue damage or disease by causing acute

This is an Open Access article licensed under a Creative Commons license: Attribution 4.0 International (CC- BY). Published by Oriental Scientific Publishing Company @ 2018 
or chronic inflammatory reactions in the heart, liver, pancreas, kidneys, brain, lungs, intestines and reproductive system.

Inflammatory cells are activated by infectious and non-infectious stimuli, as well as cell damage, which activate inflammatory signalling pathways. Inflammation occurs quickly in various disease conditions. In the cardiac stress conditions, there are higher amounts of endothelial adhesion molecules, as well as enhanced inflammatory cytokine and chemokine synthesis and its release. Excessive inflammation in the liver protects it from infection and injury but it can also cause hepatocyte loss, metabolic changes, ischemia-reperfusion injury and finally permanent hepatic impairment ${ }^{3}$. Increased inflammatory indications often precipitate unwanted chemical reactions in various body organs which ultimately results in the aggravation of unwanted conditions including bronchial asthma, inflammatory bowel disease (IBD), ankylosing spondylitis, osteoarthritis, systemic lupus erythematosus, rheumatic fever, polyarthritis nodosa and rheumatoid arthritis, etc., which leads to granuloma formation, edema and leukocyte infiltration, etc ${ }^{4}$.

In case of autoimmune diseases, like arthritis, the problem of patient reach to several folds higher than expected, since it attacks body's own tissue. Therefore, to reduce the pain and further responses, novel and potent anti-inflammatory agents are required ${ }^{5}$.

In medicine and pharmacology branch, the drug discovery is an important and continuous process to discover new pharmacologically active drug molecules with minimum toxic effects ${ }^{6,7}$.

Anti-inflammatory drugs, also known as NSAIDs, suppress the cyclooxygenase-2 (COX2) enzymes. These NSAIDs have the ability to inhibit the formation of prostaglandins (PGs). Since the discovery of aspirin (the wonder blockbuster agent), other promising candidates have emerged on the market, and the majority of heterocycles have been tested In vitro for anti-inflammatory action $^{8-10}$. However, all the experimentally and clinically approved molecules do have one or the other complications which have hindered long-term applications. Particularly in treating inflammatory conditions for a long duration range, many problems such as stomach irritation (aspirin), bleeding in the stomach (ibuprofen), cardiac problems (celecoxib), etc. are frequently appeared among the patients ${ }^{11}$. With the progress of time, new inhibitors have been developed, but the majority of them demonstrated similar complications which restricted their long term use to cure various inflammatory problems ${ }^{12-14}$.

The enzymes cyclooxygenase-1 (COX1) and cyclooxygenase-2 (COX-2) catalyse the conversion of arachidonic acid to prostaglandin (PG) $\mathrm{H} 2$, which is the progenitor of PGs and thromboxane. These lipid mediators are involved in inflammation and pain, as well as normal physiological processes. The COX enzymes work to control blood flow through kidney, stomach cell protection from gastric and duodenal ulcers and control over prostaglandin E2 (PGE2) secretion ${ }^{15-19}$. The COX-2 is a primary inflammatory target, when inhibited, produces relief from pain, fever and swelling. Extracellular and intracellular stimuli cause activation of COX2 enzymes. This in turn causes release of TNF- $a$ (Tumor Necrosis Factor) and EGF (EpidermalGrowth Factor) and endothelin etc ${ }^{20-22}$.

Other than, COX; Lipoxygenases (LOXs; $E C 1.13 .11 .12)$ are the class of non-iron-containing enzyme found in biologically active form inside the cells like basophils, neutrophils, leukocytes, mast cells, macrophages and eosinophils which has an imperative role in the biosynthesis of leukotrienes (LTs) ${ }^{23,24,25}$. The LOX enzymes catalyze stereospecific oxygenation of fatty-acid. The produced LOX mediated leukotriene $\mathrm{B}_{4}\left(\mathrm{LTB}_{4}\right)$ and peptidoleukotrienes leads to bronchoconstriction. The formation of Hydroperoxy Eicosa Tetraenoic Acids (HPETEs) from arachidonic $\mathrm{acid}^{26}$ is catalysed by LOXs. The produced HPETEs are then reduced and resulted into eicosanoids. In general, eicosanoids are considered as molecules responsible for signalling work along with its important role in the immune responses and other physiological processes ${ }^{27}$.

For the suppression of these inflammatory conditions, primarily LOX, COX-1/2, and thromboxane $\mathrm{A}_{2}$ are the key targets. Various potent phenoxyacetanilide derivatives being employed to treat various inflammatory ailments include acetaminophen, indomethacin, phenacetin, phenylbutazone and procainamide etc ${ }^{28-32}$. 
It can be said that pathways relying on the cyclooxygenase (COX) and lipoxygenase (LOX) enzymes biosynthesize arachidonic acid derived lipid mediators that are intricately implicated in inflammation. Thus the role of LOX and COX isoforms are related in pathogenesis of inflammation.

Through this research paper, an attempt has been made to synthesize some new phenoxyacetanilide derivatives with substituted phenol and these synthesised compounds would be subjected to evaluation of analgesics and antiinflammatory activity.

\section{MATERIALS AND METHODS}

\section{Chemical and Instrumentation}

The analytical grade chemicals and some standard drugs were procured from SigmaAldrich, Germany and Central Drug House, New Delhi, India. The FT-IR spectroscopic analysis was performed using the FTIR spectrometer. The ${ }^{1} \mathrm{H}-\mathrm{NMR}$ spectra of the compounds were carried out on Bruker Advance-II instrument at $400 \mathrm{MHz}$ frequency. Tetramethylsilane (TMS) was employed and the chemical shifts were expressed in ppm. For mass spectroscopic analysis MICROMASS QTOF instrument was used. Thin Layer Chromatography (TLC) on pre-coated silica gel G plate was used to study the progress of the chemical reaction. Elemental Analyzer (PerkinElmer 2400) was utilized for $\mathrm{CHN}$ analysis. The reaction scheme for synthesis of new potent phenoxyacetanilide derivatives are presented in Figure 1.

\section{Synthetic Scheme}

Where,

$\mathrm{A}=\mathrm{H} ; 2,3\left(\mathrm{CH}_{3}\right)_{2} ; 4 \mathrm{OCH}_{3} ; 2-\mathrm{CH}_{3} ; 4 \mathrm{CH}_{3} ; 2-\mathrm{COOCH}_{3} ; 4 \mathrm{Cl}$ $\mathrm{B}=\mathrm{H} ; 2,6 \mathrm{Cl}_{2} ; 2 \mathrm{COOCH}_{3}$

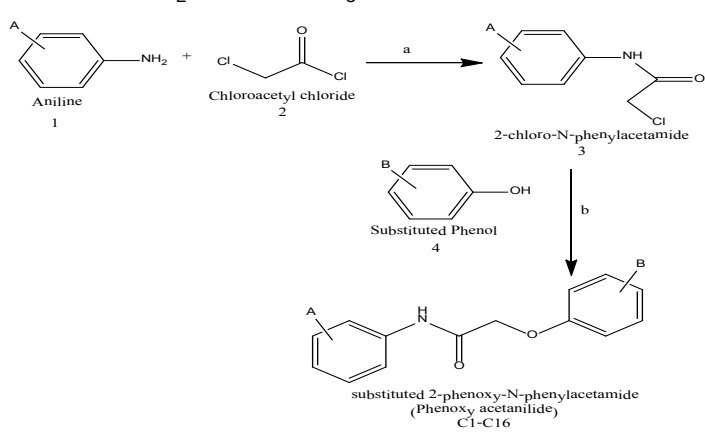

Fig. 1. Reaction scheme for synthesis of phenoxyacetanilide derivatives
Reagents used and reaction conditions: a) Ethyl methyl ketone, sodium carbonate, $7-10^{\circ} \mathrm{C}, \mathrm{p} . \mathrm{H}$ 7-8 $\mathrm{h} \mathrm{b}$ ) Substituted phenol, dry acetone, Potassium iodide, anhydrous potassium carbonate.

Synthetic procedure for 2-chloro-N-phenylacetamide ( $\omega$ - chloroacetanilide) (3)

Distilled aniline or aniline derivatives along with methyl ethyl ketone were taken into three neck round bottom flask having $500 \mathrm{~mL}$ capacity and provision was made for attachment of the mechanical stirrer and two $100 \mathrm{~mL}$ capacity funnels, already kept in an ice bath and salt. After this, solutions of chloroacetyl chloride in methyl ethyl ketone and sodium carbonate in distilled water were added through the two dropping funnels into RBF gradually. At first, after addition of some volume of the sodium carbonate solution to the reaction vessel, simultaneous dropwise solution of chloroacetyl chloride (in methyl ethyl ketone) and solution of sodium carbonate from the dropping funnels were added. This chemical reaction was performed at $7-10^{\circ} \mathrm{C}$. Finally, the $\mathrm{pH}$ of flask was ensured at basic (pH 7-8). The assembly was left as such for half an hour $(30 \mathrm{~m})$. The ice water bath and the two dropping funnels were removed. The content of flask was immersed in separating funnel with an aim to remove aqueous layer. Distilled water was used to wash the organic layer and afterwards it was transferred to a $250 \mathrm{~mL}$ conical flask to which sodium sulfate $\left(\mathrm{Na}_{2} \mathrm{SO}_{4}\right)$ was added and kept overnight. The organic layer was decanted and for removal of solvent was done at reduced pressure. The solid so obtained was recrystallized from ethanol ${ }^{33,34}$.

Synthetic procedure for substituted 2-phenoxy$\mathrm{N}$-phenylacetamide (C1-C6)

A reaction assembly consisting of a three neck round-bottomed flask (capacity $250 \mathrm{~mL}$ ) attached with mechanical stirrer and a condenser set on a water bath was used. The chloro compound $(0.01 \mathrm{M})$ and dry acetone $(40 \mathrm{~mL})$ were placed in the RBF. In RBF, after addition of phenol or substituted phenol $(0.01 \mathrm{M})$; potassium iodide $(0.2 \mathrm{~g})$ and potassium carbonate (anhydrous); the reaction mixture was subjected to mechanical stirring and afterwards reflux condensation was done upto 14-16 hours. TLC was employed to monitor the progress of reaction. In last, after proper cooling of reaction mixture at room temperature, residue was filtered and washed with acetone and solvent was removed under reduced pressure. 
The residue got solidified on cooling. For removing unreacted phenol, the solid so obtained was treated with warm $\left(45^{\circ} \mathrm{C}\right) 10 \%$ solution of sodium carbonate for $1 \mathrm{~h}$ with constant stirring. The new derivatives of phenoxy-acetanilide were collected by filtration and upon washing with distilled water, it was dried and re-crystallized in proper solvent.

The findings of spectral characterizations of all the synthesized compounds are as follows:

\section{2-phenoxy-N-phenylacetamide (C1)}

FTIR through $\mathrm{KBr}$ pressed pellet, frequency $\left(\mathrm{v} \mathrm{cm}^{-1}\right)=3249(-\mathrm{NH}$, stretching), 3088 (aromatic), $1726(\mathrm{C}=\mathrm{O}), 1637$ (-NH, bending), $1603(\mathrm{C}=\mathrm{Cstr}$, arom), 1261 (C-O); ${ }^{1} \mathrm{H}$ NMR (ס, ppm, $\mathrm{CDCl}_{3}$ ): 4.89 $(2 \mathrm{H}, \mathrm{s}), 6.9-7.1(3 \mathrm{H}, 6.96$ (dddd, J=8.2, 1.4, 1.3, 0.5 $\mathrm{Hz}), 6.95(\mathrm{tt}, \mathrm{J}=7.9,1.3 \mathrm{~Hz}), 7.07(1 \mathrm{H}, \mathrm{tt}, \mathrm{J}=7.8,1.2$ $\mathrm{Hz}$ ), 7.22-7.37 (4H, 7.27 (dddd, J=8.2, 7.8, 1.4, 0.5 $\mathrm{Hz}), 7.32$ (dddd, J=8.2, 7.8, 1.4, $0.5 \mathrm{~Hz}), 7.48(2 \mathrm{H}$, dddd, J=8.2, 1.5, 1.2, $0.5 \mathrm{~Hz}) ;{ }^{13} \mathrm{CNMR}(75 \mathrm{MHz}$, DMSO) d ppm: 121-158.1 (12C, aromatic); 66.6 (2C, $\left.\mathrm{CH}_{2}\right)$; 167.6 (1C, $\left.\mathrm{C}=\mathrm{O}\right)$; $\mathrm{MS}: \mathrm{M}+227$. Anal Calcd. for $\mathrm{C}_{14} \mathrm{H}_{13} \mathrm{NO}_{2}$ : C, 73.99; $\mathrm{H}, 5.77 ; \mathrm{N}, 6.16$. Found: $\mathrm{C}, 70.14 ; \mathrm{H}, 5.36 ; \mathrm{N}, 5.67$.

\section{2-(2,6-dichlorophenoxy)-N-phenylacetamide (C2) \\ FTIR through $\mathrm{KBr}$ presed pellet, frequency} $\left(\mathrm{v} \mathrm{cm}^{-1}\right)=3249$ (-NH, stretching), 3088 (aromatic), $1726(\mathrm{C}=\mathrm{O}), 1637$ (-NH, bending), $1603(\mathrm{C}=\mathrm{C}$, aromatic), 1261 (C-O), 777 (C-Cl); ${ }^{1} \mathrm{H}$ NMR (ס, ppm, $\left.\mathrm{CDCl}_{3}\right): 4.81(2 \mathrm{H}, \mathrm{s}), 7.07(1 \mathrm{H}, \mathrm{tt}, \mathrm{J}=7.8,1.2 \mathrm{~Hz}), 7.27$ (2H, dddd, J=8.2, 7.8, 1.4, 0.5 Hz), $7.37(1 \mathrm{H}, \mathrm{t}, \mathrm{J}=7.7$ $\mathrm{Hz}), 7.48(2 \mathrm{H}$, dddd, J=8.2, 1.5, 1.2, $0.5 \mathrm{~Hz}), 7.56$ (2H, dd, J=7.7, $1.7 \mathrm{~Hz}) ;{ }^{13} \mathrm{CNMR}$ (75 MHz, DMSO) d ppm: 121.6-153.1 (12C, aromatic); $65.6\left(2 \mathrm{C}, \mathrm{CH}_{2}\right)$; 167.6 (1C, C=O); MS: M+ 295, M+2 297. Anal Calcd for $\mathrm{C}_{14} \mathrm{H}_{11} \mathrm{CINO}_{2}$ : C, 56.78; $\mathrm{H}, 3.74 ; \mathrm{N}, 4.73$. Found: C, 52.13; H, 3.29; N, 4.17 .

\section{N-(4-methoxyphenyl)-2-phenoxyacetamide (C3)} FTIR through $\mathrm{KBr}$ pressed pellet, frequency $\left(\mathrm{v} \mathrm{cm}^{-1}\right)=3249(-\mathrm{NH}$, stretching), 3088 (aromatic), $1726(\mathrm{C}=\mathrm{O}), 1637(-\mathrm{NH}$, bending), $1603(\mathrm{C}=\mathrm{C}$, aromatic), 1261 (C-O); ${ }^{1} \mathrm{H}$ NMR ( $\delta, \mathrm{ppm}, \mathrm{CDCl}_{3}$ ): $3.75(3 \mathrm{H}, \mathrm{s}), 4.67(2 \mathrm{H}, \mathrm{s}), 6.63(2 \mathrm{H}, \mathrm{ddd}, \mathrm{J}=8.8,2.7$, $0.5 \mathrm{~Hz}$ ), 6.92-7.0 (3H, 6.96 (dddd, J=8.2, 1.4, 1.3, $0.5 \mathrm{~Hz}), 6.95(\mathrm{tt}, \mathrm{J}=7.9,1.3 \mathrm{~Hz}), 7.24-7.37(4 \mathrm{H}, 7.28$ (ddd, J=8.8, 2.3, 0.5 Hz), 7.32 (dddd, J=8.2, 7.9, $1.4,0.5 \mathrm{~Hz}$ ); ${ }^{13} \mathrm{CNMR}$ (75 MHz, DMSO) d ppm: $121-$ 158.9 (12C, aromatic); $66.6\left(2 \mathrm{C}, \mathrm{CH}_{2}\right) ; 167.6$ (1C,
$\mathrm{C}=\mathrm{O}), 55.8\left(1 \mathrm{C}, \mathrm{OCH}_{3}\right)$; MS: $\mathrm{M}+257$. Anal. Calcd. for $\mathrm{C}_{15} \mathrm{H}_{15} \mathrm{NO}_{3}: \mathrm{C}, 70.02 ; \mathrm{H}, 5.88 ; \mathrm{N}, 5.44$. Found: $\mathrm{C}$, $68.08 ; \mathrm{H}, 5.34 ; \mathrm{N}, 5.01$.

\section{2-(2,6-dichlorophenoxy)-N-(4-methoxyphenyl) acetamide (C4) \\ FTIR through $\mathrm{KBr}$ presed pellet, frequency} (v cm$\left.{ }^{-1}\right)=3249(-\mathrm{NH}$, stretching), 3088 (aromatic), $1726(\mathrm{C}=\mathrm{O}), 1637(-\mathrm{NH}$, bending $), 1603(\mathrm{C}=\mathrm{C}$, aromatic), 1261 (C-O), 777 (C-Cl); ${ }^{1} \mathrm{H}$ NMR (ס, ppm, $\left.\mathrm{CDCl}_{3}\right): 3.81(3 \mathrm{H}, \mathrm{s}), 4.69(2 \mathrm{H}, \mathrm{s}), 6.68(2 \mathrm{H}, \mathrm{ddd}$, $\mathrm{J}=8.8,2.7,0.5 \mathrm{~Hz}), 7.28(2 \mathrm{H}$, ddd, $\mathrm{J}=8.8,1.7,0.5$ $\mathrm{Hz}), 7.37(1 \mathrm{H}, \mathrm{t}, \mathrm{J}=7.7 \mathrm{~Hz}), 7.56(2 \mathrm{H}, \mathrm{dd}, \mathrm{J}=7.7,1.7$ $\mathrm{Hz}) ;{ }^{13} \mathrm{CNMR}$ (75 MHz, DMSO) d ppm: 122.6-158.9 (12C, aromatic); $65.6\left(2 \mathrm{C}, \mathrm{CH}_{2}\right) ; 167.6(1 \mathrm{C}, \mathrm{C}=\mathrm{O})$, $55.8\left(1 \mathrm{C}, \mathrm{OCH}_{3}\right)$; $\mathrm{MS}: \mathrm{M}+325, \mathrm{M}+2$ 327. Anal. Calcd. for $\mathrm{C}_{15} \mathrm{H}_{13} \mathrm{CINO}_{2}: \mathrm{C}, 55.23 ; \mathrm{H}, 4.02 ; \mathrm{N}, 4.29$. Found: C, 52.97; H, 3.72; N, 3.81 .

\section{2-phenoxy-N-(o-tolyl)acetamide (C5)}

FTIR through $\mathrm{KBr}$ presed pellet, frequency $\left(\mathrm{v} \mathrm{cm}^{-1}\right)=3249(-\mathrm{NH}$, stretching), 3088 (aromatic), $1726(\mathrm{C}=\mathrm{O}), 1637(-\mathrm{NH}$, bending $), 1603(\mathrm{C}=\mathrm{C}$, aromatic), $1446\left(-\mathrm{CH}_{3}\right.$, bending), 1261 (C-O); ${ }^{1} \mathrm{H}$ NMR $\left(\delta, \mathrm{ppm}, \mathrm{CDCl}_{3}\right): 2.20(3 \mathrm{H}, \mathrm{s}), 4.68(2 \mathrm{H}, \mathrm{s}), 6.95(1 \mathrm{H}$, $\mathrm{tt}, \mathrm{J}=7.9,1.3 \mathrm{~Hz}), 6.93-7.12(5 \mathrm{H}, 7.03$ (ddd, J=7.8, 7.5, $1.1 \mathrm{~Hz}$ ), 7.08 (ddd, J=7.8, 1.8, $0.5 \mathrm{~Hz}$ ), 6.97 (dddd, J $=8.2,1.4,1.3,0.5 \mathrm{~Hz}$ ), 7.09 (ddd, J=8.2, 1.4, 1.3, 0.5 $\mathrm{Hz}), 7.21-7.37(3 \mathrm{H}, 7.26$ (ddd, J=8.54, $7.51 .8 \mathrm{~Hz}$ ), 7.32 (dddd, J=8.2, 7.9, 1.4, 0.5); ${ }^{13} \mathrm{CNMR}(75 \mathrm{MHz}$, DMSO) d ppm: 121-158.1 (12C, aromatic); 66.6 (2C, $\left.\mathrm{CH}_{2}\right) ; 167.6(1 \mathrm{C}, \mathrm{C}=\mathrm{O}), 17.3\left(1 \mathrm{C}, \mathrm{CH}_{3}\right)$; $\mathrm{MS}: \mathrm{M}+241$. Anal. Calcd. for $\mathrm{C}_{15} \mathrm{H}_{15} \mathrm{NO}_{2}: \mathrm{C}, 74.67 ; \mathrm{H}, 6.27 ; \mathrm{N}, 5.81$. Found: C, 71.22; $\mathrm{H}, 5.79 ; \mathrm{N}, 5.35$.

\section{2-(2, 6-dichlorophenoxy)-N-(o-tolyl)acetamide (C6)}

FTIR through $\mathrm{KBr}$ presed pellet, frequency $\left(\mathrm{v} \mathrm{cm}^{-1}\right)=3249(-\mathrm{NH}$, stretching), 3088 (aromatic), 1726 $(\mathrm{C}=\mathrm{O}), 1637$ ( $-\mathrm{NH}$, bending), $1603(\mathrm{C}=\mathrm{C}$, aromatic), 1446 ( $-\mathrm{CH}_{3}$, bending), 1261 (C-O), 718 (C-Cl); ${ }^{1} \mathrm{HNMR}$ $\left(\delta, \mathrm{ppm}, \mathrm{CDCl}_{3}\right): 2.20(3 \mathrm{H}, \mathrm{s}), 4.61(2 \mathrm{H}, \mathrm{s}), 6.98-7.12$ $(3 \mathrm{H}, 7.03$ (ddd, J=7.8, 7.5, 1.1 Hz), 7.08 (ddd, 7.8, 1.8, $0.5 \mathrm{~Hz}), 7.09$ (ddd, J=8.4, 1.1, 0.5 Hz), $7.26(1 \mathrm{H}$, ddd, $\mathrm{J}=8.4,7.5,1.8 \mathrm{~Hz}), 7.37(1 \mathrm{H}, \mathrm{t}, \mathrm{J}=7.7 \mathrm{~Hz}), 7.56(2 \mathrm{H}$, $\mathrm{dd}, \mathrm{J}=7.7,1.7 \mathrm{~Hz}$ ); ${ }^{13} \mathrm{CNMR}(75 \mathrm{MHz}$, DMSO) d ppm: 126.4-153.1 (12C, aromatic); $65.6\left(2 \mathrm{C}, \mathrm{CH}_{2}\right) ; 167.6$ (1C, C=O), $17.3\left(1 \mathrm{C}, \mathrm{CH}_{3}\right)$; $\mathrm{MS}: \mathrm{M}+309, \mathrm{M}+2311$. Anal. Calcd. for $\mathrm{C}_{15} \mathrm{H}_{13} \mathrm{Cl}_{2} \mathrm{NO}_{2}: \mathrm{C}, 58.08 ; \mathrm{H}, 4.22 ; \mathrm{N}$, 4.52. Found: $\mathrm{C}, 56.16 ; \mathrm{H}, 3.77 ; \mathrm{N}, 4.03$. 


\section{Computational Evaluation}

Computational evaluation of physochemical properties of all the synthesised compounds and standard compounds was done by the software Chem 3-D; Ultra-version, 8.0 \& 12.0. The literature review concluded that physicochemical properties of compounds are employed to predict the properties viz. adsorption, distribution, metabolism and excretion since a long time ${ }^{35}$.

\section{Docking Studies}

Docking study was performed of the synthesized compounds ( $\mathrm{C} 1$ to $\mathrm{C} 6$ ) on COX-2 enzyme with the help of AutoDock Vina software. The findings of docking study were matched with the value of diclofenac sodium and Indomethacin. Inhibition of COX-2 enzyme exhibits the achievement towards analgesic and anti-inflammatory activity.

Protein data bank (PDB) was used for collection of multi-chain protein crystal structure with PDB ID: 6BL3. ChemDraw/ChemSketch editor was utilized to drawn the two dimensional (2D) structures of synthesized molecules. Dot mole (.mol) file was used for structure format. The saved 2D structures were further converted into 3D structure and using the geometry of structure, lowest energy state was calculated. Protein Data Bank (pdb) file format was employed for 3D structures and after saving the structures in pdb format, docking study was executed. For docking, several poses of each ligand was generated using software and; the pose of ligand with binding energy $(\mathrm{kcal} / \mathrm{mol})$ values in negative was considered. The docking pose with maximum negative binding energy is generally considered as best for fitting at target.

\section{ADME analysis}

The accomplishment of a potent synthesised molecule is identified not simply by its fine prospective rather besides by a reasonable ADME report. Because a broad multiplicity of investigational methods and far above the ground throughput in vitro ADME displays are presented and these have the ability to expect a number of in silico outcomes and is necessary to examine the better superiority of newly synthesized compounds. In the current drug discovery process, computational ADME should be evaluated using In vivo and In vitro models for reduced safety issues.

\section{Evaluation of COX2 inhibitory effect through In vitro methods}

In order to test the COX2 inhibitory effect of the target compounds $\mathrm{C} 1$ to $\mathrm{C} 6$, COX-Inhibition kit was used. Indomethacine and Diclofenac sodium were utilized as standard compounds. Diclofenac sodium provides effective and better analgesia than other known NSAIDs therefore used as standard for analgesic activity ${ }^{36}$.

\section{Biological Evaluation \\ Experimental Animals}

Rats weighing 150-250 g, of either sex (male or female), were used to measure the biological activities. Procurement of the animals for the present study was done from the Animal House, IFTM University, Moradabad-244102, UP. The laboratory conditions (temperature 22 to $26^{\circ} \mathrm{C}$ and humidity 30 to $70 \%$ were maintained with a dark and light cycle $(12 / 12 \mathrm{~h})$ for the animals in polyacrylic cages. The animals were fed with standard pellets diet fresh water ad libitium. Before the experimentation, all of the animals were acclimatised to laboratory conditions for a week. The procedures employed for animal based experimentation in present study were properly reviewed, discussed and finally approved by duly constituted the Institutional Animal Ethics Committee with approval code 2017/837ac/Ph.D./02.

\section{Preparation of Test Compounds}

Tween $80(1 \%)$ was used to make a suspension of the reference and test samples. The first group (control) was given a $0.1 \mathrm{~mL}$ Tween 80 suspension orally. The second group (standard) was given an oral dose of Indomethacin or diclofenac sodium (20 mg/kg body weight). All synthesized compounds were given to the animals orally at a concentration of $100 \mathrm{mg} / \mathrm{kg}$ b.w.

\section{Acute toxicity Studies}

The acute toxicity study was carried out in accordance with the guidelines of organization for Economic Co-Operation and Development (OECD) to perform the acute toxicity related work. The animals were divided into groups of 6 animals in each group $(n=6)$. On the day of the biological evaluation, animals were given, the test compounds in different dose of 10,20,100, 200 and $1000 \mathrm{mg} /$ $\mathrm{kg}$ b.w through oral route. Three hour time was given for observation of any frequent behavioural, neurological, autonomic response of animals. The 
examination was continued for $24 \mathrm{~h}$ with gap of every $30 \mathrm{~m}$ or till death.

Animals exhibited their safety up to the highest dose of $1000 \mathrm{mg} / \mathrm{kg} \mathrm{b.w.,} \mathrm{but} \mathrm{small}$ behavioural manifestations like touch sensitivity, alertness, and restlessness were observed. Thus, the study used one tenth of the appropriate dose, i.e. $100 \mathrm{mg} / \mathrm{kg}$ b.w.

\section{Evaluation of Anti-Inflammatory Response Carageenan induced Paw-Edema Model}

The anti-inflammatory response of the newly synthesized acetanilide derivatives was screened according to the procedures of carrageenan-induced paw-edema model ${ }^{37}$. The rats were fasted overnight to reduce the variation in the edema. Distilled water $(5 \mathrm{~mL})$ was orally administered to individual rats before the beginning of the experiment. The synthesised compounds (100 mg/kg b.w.) were given through oral route to the test group $(n=6)$ once by suspending in $5 \%$ acacia solution before the initiation of inflammation. For producing the edema, injection of $0.1 \mathrm{~mL}$ of $1 \%$ carrageenan solution into the subplantar part of hind paw of rats through the subcutaneous method was given. A black mark using marker was made on each used rats at their left hind paw just beyond the tibio-tarsal junction of the leg to indicate the level in which the hind paw could be dipped in the column. The marking helps to ensure that constant paw volume is at every time. The mercury displacement method was used to determine each rat's initial paw volume. The rat hind paw volume was measured by a plethysmometer in $0,1,2$, and $3 \mathrm{~h}$ respectively after the carrageenin suspension injection.

The disparity between the width of injected and non-injected paws provides the information regarding the potential of the compounds in reducing the edema. The control group received $5 \%$ acacia solution orally. Indomethacin (10 mg/kg b.w.) served as positive control ${ }^{38}$.

The values of mean \pm standard error were used to mention the findings of the study. In order to calculate the the percent inhibition, under mentioned formula was employed:

$\%$ inhibition $(I)=(1-V t / V c) \times 100$
Where, $\mathrm{Vt}$ and $\mathrm{Vc}$ indicate the mean change in paw volume of rats (treated and control) respectively.

\section{Evaluation of Analgesic Response Eddy's Hot-Plate Model}

The Eddy's hot-plate model was used to screen all of the produced compounds for analgesic efficacy ${ }^{39,40}$. The rats were subjected to the sensitivity test by employing hot plate method. This test model involved the use of hot place as an electrically heated surface equipped with temperature control at temperature $55-56^{\circ} \mathrm{C}$. The rats which lifted the tail on the heated plate within the duration of 5 seconds were chosen for the analgesic study. The rats in the test group $(n=6)$ received compounds $(100 \mathrm{mg} / \mathrm{kg}$ b.w.) through oral route. The lower part of rat tail $(5 \mathrm{~cm})$ was provided a black mark using marker. This was done for each animal.

The animals were screened by placing their distal part of the tail $(5 \mathrm{~cm})$ on the hot plate, exactly at $55-56^{\circ} \mathrm{C}$. The reaction time at which mice withdraw the tail was measured at $0,1,2$, and $3 \mathrm{~h}$, respectively. The study was ended $15 \mathrm{sec}$ after their assignment on the hot plate to avoid injury to the tail. The control group received normal saline $(3 \mathrm{~mL} /$ $\mathrm{kg}$ b.w.). The dose for positive control (Diclofenac Sodium) was (10 mg/kg) b.w.).

\section{RESULTS AND DISCUSSION}

\section{Synthetic Chemistry}

New acetanilide derivatives were prepared by refluxing various 2-chloro- $\mathrm{N}$-phenylacetamide with a number of substituted phenols. The newly synthesized acetanilide derivatives were characterized by IR, ${ }^{1} \mathrm{HNMR},{ }^{13} \mathrm{CNMR}$, Mass spectroscopy including $\mathrm{CHN}$ analysis commonly called as elemental analysis.

2-chloro-N-phenylacetamide was synthesized by using chloroacetylation reaction of aniline and its derivatives with chloroacetyl chloride in basic medium. Various substituted 2-phenoxy$\mathrm{N}$-phenylacetamide were prepared by reacting chloro compounds with various phenols. During the reaction, potassium iodide and potassium carbonate (anhy.) in acetone were also added in reaction mixture. Physical characterization findings are expressed in Table 1. 
Table 1: Physical characterization of all the synthesized compounds

\begin{tabular}{|c|c|c|c|c|c|c|c|c|c|c|c|c|}
\hline Code & $A$ & $B$ & Structure & \multicolumn{2}{|c|}{ M. P. $\left({ }^{\circ} \mathrm{C}\right)$} & \multicolumn{2}{|c|}{ Mol. Formula } & \multicolumn{2}{|c|}{ Mol. weight $\mathrm{g} / \mathrm{mol}$} & \multicolumn{2}{|c|}{ \%Yield } & $\mathrm{R}_{f}$ Value \\
\hline C1 & $\mathrm{H}$ & $\mathrm{H}$ & & \multicolumn{2}{|c|}{$112-117$} & $\mathrm{C}_{14} \mathrm{H}_{13} \mathrm{~N}$ & $\mathrm{IO}_{2}$ & \multicolumn{2}{|l|}{227} & \multicolumn{2}{|c|}{71.23} & 0.87 \\
\hline $\mathrm{C} 2$ & $\mathrm{H}$ & $2,6-\mathrm{Cl}_{2}$ & & \multicolumn{2}{|c|}{$118-120$} & $\mathrm{C}_{14} \mathrm{H}_{11} \mathrm{Cl}_{2}$ & $\mathrm{NO}_{2}$ & \multicolumn{2}{|l|}{296} & \multicolumn{2}{|c|}{76.27} & 0.93 \\
\hline C3 & $4-\mathrm{OCH}_{3}$ & $\mathrm{H}$ & & \multicolumn{2}{|c|}{$126-128$} & $\mathrm{C}_{15} \mathrm{H}_{15} \mathrm{~N}$ & $\mathrm{JO}_{3}$ & \multicolumn{2}{|l|}{257} & \multicolumn{2}{|c|}{73.92} & 0.65 \\
\hline C4 & $4-\mathrm{OCH}_{3}$ & $2,6-\mathrm{Cl}_{2}$ & & \multicolumn{2}{|c|}{$111-113$} & $\mathrm{C}_{15} \mathrm{H}_{13} \mathrm{CII}$ & $\mathrm{NO}_{2}$ & \multicolumn{2}{|l|}{274.5} & \multicolumn{2}{|c|}{82.82} & 0.80 \\
\hline C5 & $2-\mathrm{CH}_{3}$ & $\mathrm{H}$ & & \multicolumn{2}{|c|}{$84-86$} & $\mathrm{C}_{15} \mathrm{H}_{15} \mathrm{~N}$ & $\mathrm{JO}_{2}$ & \multicolumn{2}{|l|}{241} & \multicolumn{2}{|c|}{70.53} & 0.95 \\
\hline C6 & $2-\mathrm{CH}_{3}$ & $2,6-\mathrm{Cl}_{2}$ & & \multicolumn{2}{|c|}{$102-103$} & \multicolumn{2}{|c|}{$\mathrm{C}_{15} \mathrm{H}_{13} \mathrm{Cl}_{2} \mathrm{NO}_{2}$} & \multicolumn{2}{|l|}{310} & \multicolumn{2}{|c|}{74.19} & 0.88 \\
\hline \multirow{8}{*}{\multicolumn{5}{|c|}{$\begin{array}{l}\text { Computational Evaluation } \\
\text { Lipophilicity reflects most important effect } \\
\text { on solubility and ADME profile with pharmacological } \\
\text { activity. The molecules with high lipophilicity, it will } \\
\text { partition into the lipid interior of membranes. If the } \\
\text { molecules are having higher log } \mathrm{P} \text {, this indicates } \\
\text { the low solubility of drug molecule whereas in lower } \\
\text { log } \mathrm{P} \text {, the drug has difficulty to penetrate the lipid } \\
\text { membranes }{ }^{41} \text {. }\end{array}$}} & \multicolumn{8}{|c|}{$\begin{array}{l}\text { Table 2: Physochemical properties of all the } \\
\text { synthesised compounds and standard compounds. }\end{array}$} \\
\hline & & & & & \multicolumn{2}{|c|}{ S. No. } & $\log P$ & $\begin{array}{c}\text { Molar } \\
\text { refractivity }\end{array}$ & HBA\& & ${ }^{*} \mathrm{HBD}$ & \#TPSA & @NRB \\
\hline & & & & & $\mathrm{C} 1$ & & 2.66 & 6.68 & 2 & 1 & 38.33 & 5 \\
\hline & & & & & $\mathrm{C} 2$ & & 3.90 & 7.66 & 2 & 1 & 38.33 & 5 \\
\hline & & & & & $\mathrm{C} 3$ & & 2.56 & 7.30 & 3 & 1 & 47.56 & 6 \\
\hline & & & & & $\mathrm{C} 4$ & & 3.81 & 8.28 & 3 & 1 & 47.56 & 6 \\
\hline & & & & & $\mathrm{C} 5$ & & 2.88 & 7.14 & 2 & 1 & 38.33 & 5 \\
\hline & & & & & $\mathrm{C} 6$ & & 4.13 & 8.13 & 2 & 1 & 38.33 & 5 \\
\hline & Sig & nificar & נlar prop & ere & & $\begin{array}{l}\text { lofenac } \\
\text { dium }\end{array}$ & 4.75 & 86.3 & 3 & 1 & 52.16 & 4 \\
\hline calct & ulated, in & luding & cular wei & gen & & omethacin & 4.27 & 94.81 & 4 & 1 & 68.5 & 4 \\
\hline
\end{tabular}

bond acceptor, hydrogen bond donor, total polar surface area, number of rotatable bonds, and molar refractivity. The drug like properties of all the synthesized compounds and reference standard compounds are mentioned in Table 2. All of the synthesised compounds had log $P$ values less than 5.6. The number of rotatable bonds (nRB) is the number of bonds that may freely rotate around each other. These synthesized compounds are suitable for oral bioavailability because they have nRB less than 10 .

Because the calculated Total Polar Surface Area (TPSA) is smaller than $140 \AA 2$, all produced chemicals are capable of permeating the cell.

\&Hydrogen Bond Acceptor,

*Hydrogen Bond Donor,

\#Total Polar Surface Area

@ Number of Rotatable Bond

\section{Molecular Docking Studies}

In computational chemistry, molecular docking is used to thoroughly explore ligands. It has resulted in tremendous progress in the field of medicinal chemistry in terms of drug discovery and design ${ }^{42}$.

The synthesised compounds ( $\mathrm{C} 1$ to $\mathrm{C} 6$ ) were docked into the human COX-2 enzyme using AutoDock Vina software. All docked chemicals were 
identified with the binding pocket's hydrophobic region. Ser-530 was shown to be the most impacted amino acid residue by hydrogen bond interaction in Indomethacin and Diclofenac sodium. This information, together with binding affinity, was used as a benchmark for COX-2 interaction. It should be noticed that $\mathrm{C} 5$ and $\mathrm{C} 6$ showed lower binding affinity than $\mathrm{R} 1$ and $\mathrm{R} 2$ and also showed interaction with Ser 530. Table 3 summarises the docking related findings. Binding interaction of R-1 as Indomethacin drug and binding interaction of R-2 as Diclofenac Sodium is presented in Fig. 2 (A\&B). Docked poses of test compounds $\mathrm{C} 1-\mathrm{C} 6$ in $\mathrm{COX}-2$ enzyme are presented in Fig. 3-5 (A \& B).

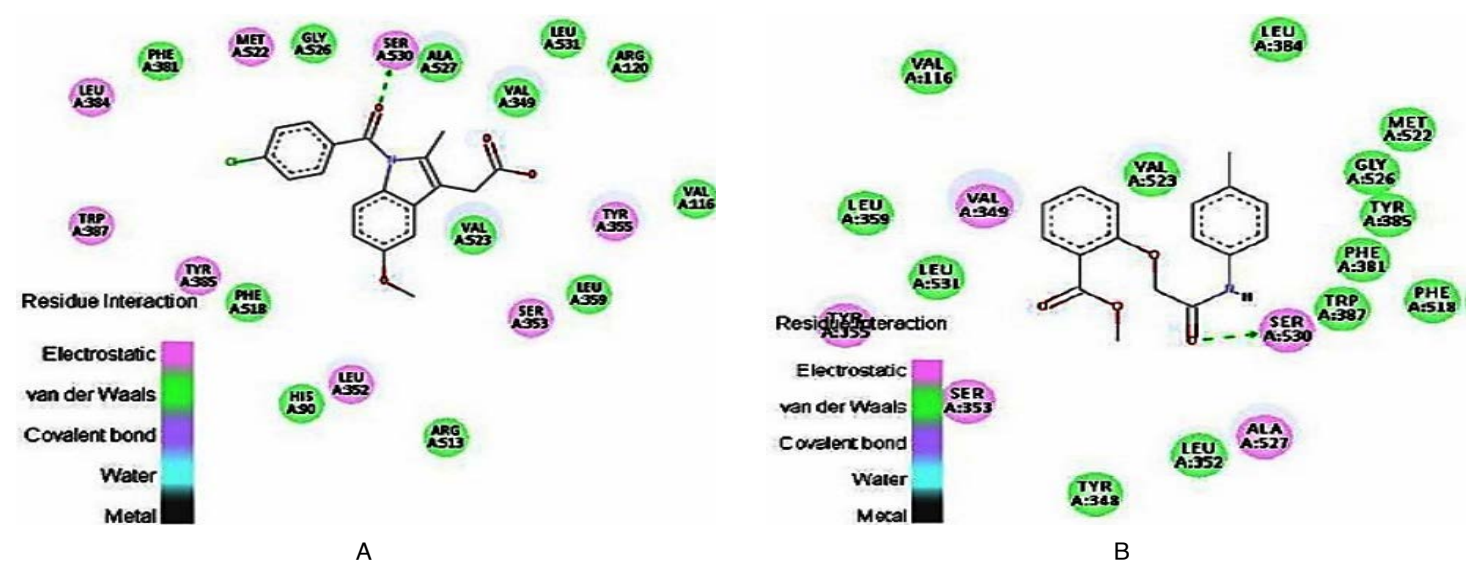

Fig. 2. Binding interaction of R-1 as Indomethacin drug (B) Binding interaction of R-2 as Diclofenac Sodium

SEA

A난,
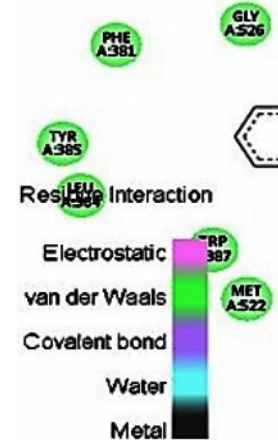

MET

\section{Givi}

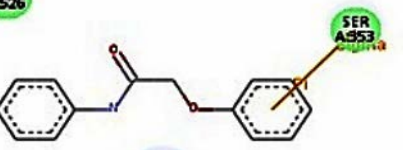

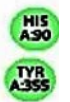

A

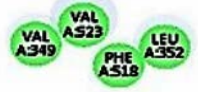

Fig. 3. Binding interaction of $\mathrm{C} 1$ (B) Binding interaction of $\mathrm{C2}$

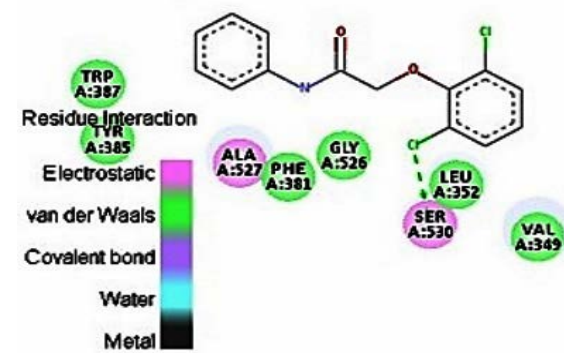

B
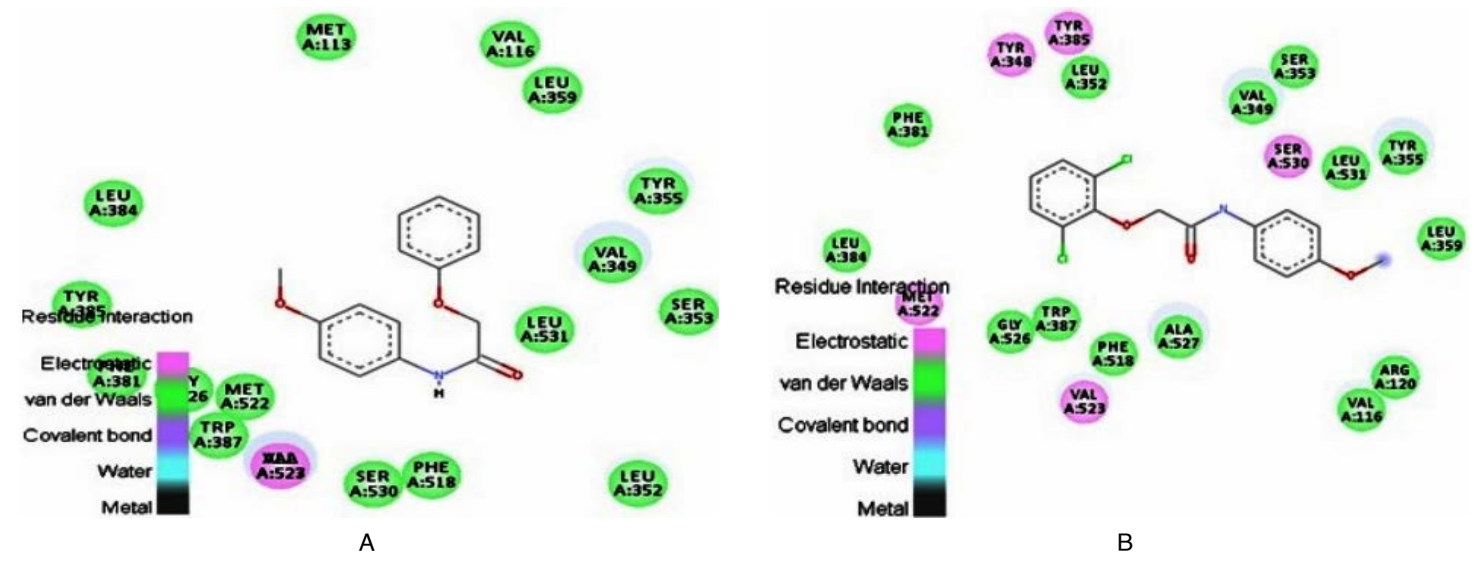

MAET

VAL AE: TrR
A:355

Fig. 4. (A) Binding interaction of $\mathrm{C3}$ (B) Binding interaction of $\mathrm{C} 4$ 

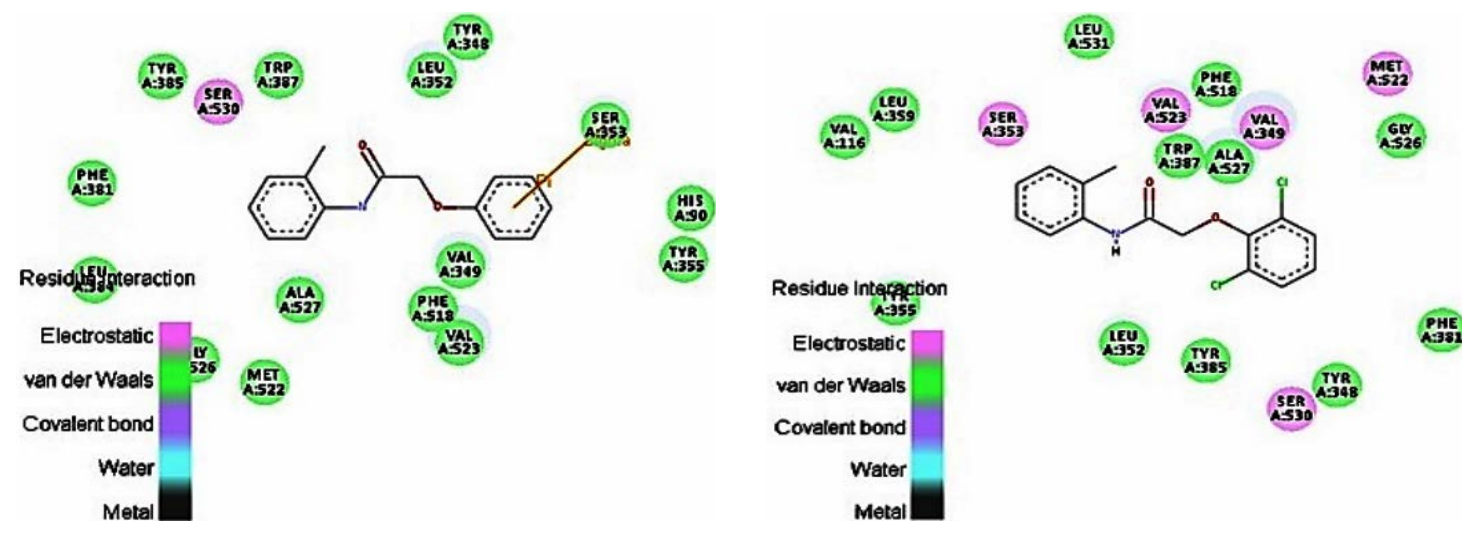

A

B

Fig. 5. Binding interaction of C5 (B) Binding interaction of $\mathrm{C6}$

Table 3: Binding affinity of synthesized compounds and In vitro COX-2 enzyme inhibition data for the synthesized compounds

\begin{tabular}{|c|c|c|}
\hline Codes of Synthesized Compounds & Binding Energy/Affinity (Kcal/Mol) & IC50 (microM) \\
\hline $\mathrm{R}-1$ & -10.2 & 46.10 \\
\hline $\mathrm{R}-2$ & -8.5 & 25.64 \\
\hline $\mathrm{C} 1$ & -7.9 & 110.25 \\
\hline C2 & -8.0 & 65.26 \\
\hline C3 & -7.9 & 75.28 \\
\hline $\mathrm{C} 4$ & -7.9 & 141.10 \\
\hline C5 & -8.2 & 205.86 \\
\hline C6 & -8.3 & 39.26 \\
\hline
\end{tabular}

Figure 6 shows a bioavailability radar pink region depicts the permissible values of the graph of new acetanilide derivatives (C1-C6) (the molecule's drug similarity qualities).

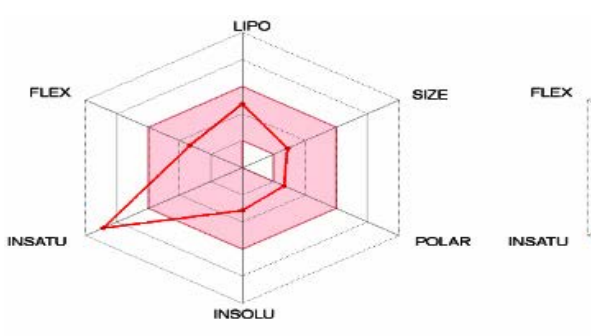

C1

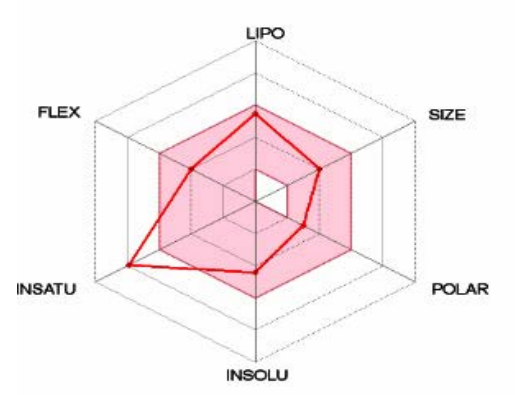

C4

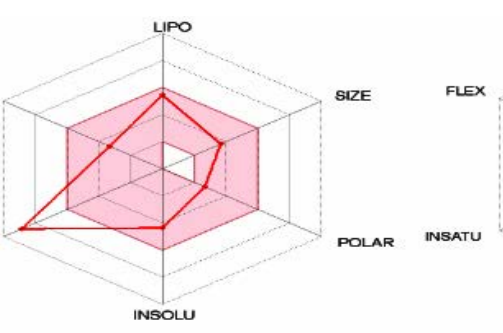

$\mathrm{C} 2$

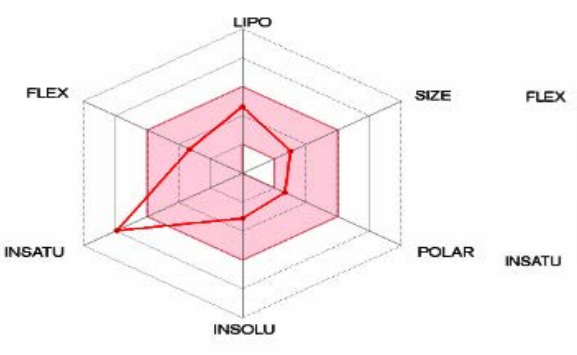

C5

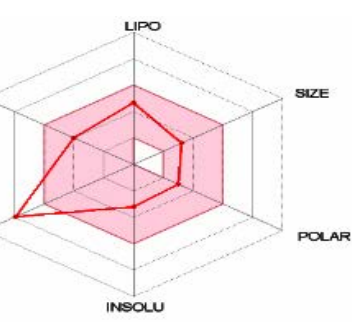

C3

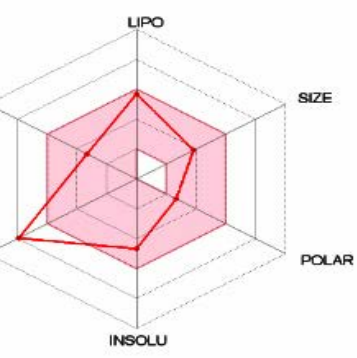

C6

Fig. 6. Bioavailability radar graph of new acetanilide derivatives (C1-C6). In diagram, drug likeness properties of the synthesized compounds are presented by pink colour 


\section{ADME Properties}

A drug candidate is called potent by a acceptable ADME report. It has become foreseeable to tell the main properties utilising in silico models due to a wide variety of experimental information and high throughput In vitro ADME values. In order to limit the number of safety hazards, it is now recommended to employ computational values of ADME attributes during the drug discovery process ${ }^{43}$.
The synthesised compounds that were evaluated demonstrated high Gl absorption and could potentially be CNS active candidates due to their ability to cross the Blood brain barrier (BBB). All the tested compounds are non-inhibitors of P-gp. All the tested compounds are inhibitors of CYP1A2 inhibitor and CYP2C19. Pharmacokinetic/ADME properties of synthesized compounds are presented in Table 4.

Table 4: Pharmacokinetic/ADME properties of the synthesized acetanilide derivatives

\begin{tabular}{|c|c|c|c|c|c|c|c|c|c|}
\hline \multirow[t]{2}{*}{ Code } & \multicolumn{9}{|c|}{ Various Pharmacokinetic Parameters } \\
\hline & $\begin{array}{c}\text { Gl } \\
a_{b s}^{a}\end{array}$ & $\begin{array}{c}\text { BBB } \\
\text { permeant }^{\mathrm{b}}\end{array}$ & $\begin{array}{c}\text { P-gp } \\
\text { substrate }^{c}\end{array}$ & $\begin{array}{l}\text { CYP1A2 } \\
\text { inhibitor }^{d}\end{array}$ & $\begin{array}{l}\text { CYP2C19 } \\
\text { inhibitore }\end{array}$ & $\begin{array}{l}\text { CYP2C9 } \\
\text { inhibitor }^{f}\end{array}$ & $\begin{array}{l}\text { CYP2D6 } \\
\text { inhibitor }^{9}\end{array}$ & $\begin{array}{l}\text { CYP3A4 } \\
\text { inhibitor }^{\text {h }}\end{array}$ & $\log K p^{i}$ \\
\hline $\mathrm{C} 1$ & High & Yes & No & Yes & Yes & No & Yes & No & $-5.75 \mathrm{~cm} / \mathrm{s}$ \\
\hline $\mathrm{C} 2$ & $\begin{array}{c}\text { Moderate to } \\
\text { High }\end{array}$ & Yes & No & Yes & Yes & Yes & Yes & No & $-5.23 \mathrm{~cm} / \mathrm{s}$ \\
\hline C3 & High & Yes & No & Yes & Yes & No & Yes & No & $-5.95 \mathrm{~cm} / \mathrm{s}$ \\
\hline $\mathrm{C} 4$ & High & Yes & No & Yes & Yes & Yes & Yes & Yes & $-5.44 \mathrm{~cm} / \mathrm{s}$ \\
\hline C5 & High & Yes & No & Yes & Yes & No & Yes & No & $-5.96 \mathrm{~cm} / \mathrm{s}$ \\
\hline C6 & High & Yes & No & Yes & Yes & Yes & Yes & Yes & $-5.05 \mathrm{~cm} / \mathrm{s}$ \\
\hline
\end{tabular}

aGastrointestinal absorption

bblood-brain barrier permeant

${ }^{c} \mathrm{P}$-glycoprotein substrate

${ }^{d}$ Cytochrome P450 1A2 inhibitor

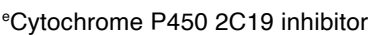

fCytochrome P450 family 2 subfamily C member 9 inhibitor

${ }^{9}$ Cytochrome P450 2D6 inhibitor

\section{In vitro Cyclooxygenase inhibitory activity}

The inhibition action of synthesized target compounds $\mathrm{C} 1$ to $\mathrm{C} 6$ on COX-2 enzymes was tested by using COX Inhibitor Screening Kit. As reference substances, Indomethacine and Diclofenac sodium were used. The findings are showed in Table 3. The findings of In vitro Cyclooxygenase inhibitory action are indicating that out of all the synthesized compounds, maximum COX-2 inhibitory action was observed for C6 [Methyl 2-(2-oxo-2-(p-tolylamino) ethoxy)benzoate].

\section{Pharmacology}

Over the evaluated range of $25 \mathrm{mg} /$ $\mathrm{kg}$ to $100 \mathrm{mg} / \mathrm{kg}$, the synthesized acetanilide derivatives showed no significant toxic effects. The synthesised compounds were found to be safe and pharmacological evaluaton was carried out at a dose of $100 \mathrm{mg} / \mathrm{kg}$ body weight.
The newly synthesised compounds were tested In vivo for anti-inflammatory action using the conventional carrageenan-induced paw edema method.

Table 5 shows the results of the Carrageenan produced rat paw edoema method. Compound C6 [Methyl 2-(2-oxo-2-(p-tolylamino)ethoxy)benzoate] exhibited the better anti-inflammatory activity with $73.36 \%$ inhibition at 120 min when compared with Indomethacin.

The analgesic activity was assessed using Eddy's hot plate method. The obtained data are showed in Table 6. Synthesized compound C5 [2-phenoxy-N-(o-tolyl)acetamide] exhibited highest analgesic activity at $2 \mathrm{~h}$ with paw licking response 4.9 second 
Table 5: Anti-inflammatory activities of synthesized compounds

\begin{tabular}{|c|c|c|c|c|c|c|c|c|c|c|c|}
\hline \multirow[t]{2}{*}{ Treatment } & \multirow[t]{2}{*}{ dose } & \multicolumn{4}{|c|}{ Mean change in Paw Volume } & \multicolumn{6}{|c|}{$\%$ inhibition $(1-V t / V c)^{\times} 100$} \\
\hline & & $0 \mathrm{~m}$ & $60 \mathrm{~m}$ & $120 \mathrm{~m}$ & $180 \mathrm{~m}$ & $240 m$ & $0 \mathrm{~m}$ & $60 \mathrm{~m}$ & $120 \mathrm{~m}$ & $180 \mathrm{~m}$ & $240 m$ \\
\hline $\begin{array}{l}\text { Group } 1 \\
\text { (Control) }\end{array}$ & $5 \mathrm{ml} / \mathrm{kg}$ & 0 & $0.516 \pm 0.14$ & $0.572 \pm 0.17$ & $0.631 \pm 0.19$ & $0.585 \pm 0.10$ & ---- & ---- & ---- & ---- & ---- \\
\hline $\begin{array}{l}\text { Group } 2 \\
\text { (Indomethacin) }\end{array}$ & 10 & 0 & $0.157 \pm 0.10^{\star \star \star}$ & $0.161 \pm 0.09^{\star \star \star}$ & $0.169 \pm 0.06^{\star * \star}$ & $0.182 \pm 0.09^{* * *}$ & 0 & 69.57 & 71.85 & 73.21 & 68.88 \\
\hline Group $3(\mathrm{C}-1)$ & 100 & 0 & $0.239 \pm 0.18^{\star \star}$ & $0.256 \pm 0.08^{\star \star}$ & $0.313 \pm 0.09^{\star *}$ & $0.311 \pm 0.01^{*}$ & 0 & 53.68 & 55.24 & 50.39 & 46.83 \\
\hline Group 4 (C-2) & 100 & 0 & $0.232 \pm 0.16^{\star \star}$ & $0.255 \pm 0.07^{\star \star}$ & $0.314 \pm 0.08^{\star \star}$ & $0.310 \pm 0.02^{\star}$ & 0 & 55.03 & 55.41 & 50.23 & 47.00 \\
\hline Group 5 (C-3) & 100 & 0 & $0.235 \pm 0.10^{\star *}$ & $0.239 \pm 0.04^{\star \star}$ & $0.311 \pm 0.09^{\star *}$ & $0.296 \pm 0.70^{\star *}$ & 0 & 54.45 & 58.21 & 50.71 & 49.40 \\
\hline Group 6 (C-4) & 100 & 0 & $0.241 \pm 0.03^{\star *}$ & $0.261 \pm 0.05^{\star \star}$ & $0.312 \pm 0.07^{\star \star}$ & $0.317 \pm 0.80^{\star}$ & 0 & 53.29 & 54.37 & 50.55 & 45.81 \\
\hline Group 7 (C-5) & 100 & 0 & $0.242 \pm 0.16^{\star \star}$ & $0.262 \pm 0.07^{\star \star *}$ & $0.329 \pm 0.09^{\star *}$ & $0.318 \pm 0.03^{\star}$ & 0 & 53.10 & 54.19 & 47.86 & 45.64 \\
\hline Group 8 (C-6) & 100 & 0 & $0.211 \pm 0.12^{\star \star}$ & $0.221 \pm 0.08^{\star * *}$ & $0.258 \pm 0.06^{\star \star}$ & $0.279 \pm 0.04^{\star *}$ & 0 & 59.10 & 73.36 & 59.11 & 52.30 \\
\hline
\end{tabular}

All the data are expressed as mean \pm SEM (standard error of mean; each group was comprised of 6 animals; $P$ value $<0.01$ significant. One-way ANOVA followed by Dunnett's multiple comparisons test was used.

Table 6: The outcome of analgesic activity by hot plate method

\begin{tabular}{|c|c|c|c|c|c|}
\hline \multirow[t]{2}{*}{ Treatment } & \multirow[t]{2}{*}{ Dose $(\mathrm{mg} / \mathrm{kg})$ Body weight } & \multicolumn{4}{|c|}{ Analgesic response by hot plate methodMean Time in Min. \pm SEM } \\
\hline & & $0 \mathrm{~min}$ & $1 \mathrm{~h}$ & $2 \mathrm{~h}$ & $3 \mathrm{~h}$ \\
\hline Group 1 (Control) & $3 \mathrm{ml} / \mathrm{kg}$ & $2.2 \pm 0.11$ & $2.3 \pm 0.14$ & $3.1 \pm 0.16$ & $3.0 \pm 0.12$ \\
\hline Group 2 (Diclofenac Sodium) & $10 \mathrm{mg} / \mathrm{kg}$ & $3.4 \pm 0.12^{\star \star *}$ & $4.2 \pm 0.13^{* \star *}$ & $10.1 \pm 0.14^{\star \star \star}$ & $8.1 \pm 0.15^{\star \star \star}$ \\
\hline Group $3(\mathrm{C}-1)$ & $100 \mathrm{mg} / \mathrm{kg}$ & $2.1 \pm 0.14$ & $3.0 \pm 0.12^{* *}$ & $3.7 \pm 0.17^{\star \star \star}$ & $2.5 \pm 0.11$ \\
\hline Group 4 (C-2) & $100 \mathrm{mg} / \mathrm{kg}$ & $2.3 \pm 0.15^{\star}$ & $3.1 \pm 0.13^{\star \star}$ & $3.9 \pm 0.15^{\star \star \star}$ & $2.4 \pm 0.16$ \\
\hline Group 5 (C-3) & $100 \mathrm{mg} / \mathrm{kg}$ & $2.2 \pm 0.11$ & $3.6 \pm 0.14^{\star \star}$ & $4.7 \pm 0.17^{\star \star \star}$ & $3.5 \pm 0.13^{\star *}$ \\
\hline Group 6 (C-4) & $100 \mathrm{mg} / \mathrm{kg}$ & $3.1 \pm 0.16^{*}$ & $3.7 \pm 0.15^{\star \star}$ & $3.9 \pm 0.12^{\star \star \star}$ & $3.6 \pm 0.10^{*}$ \\
\hline Group 7 (C-5) & $100 \mathrm{mg} / \mathrm{kg}$ & $3.5 \pm 0.14^{\star \star}$ & $3.8 \pm 0.16^{\star *}$ & $4.9 \pm 0.11^{\star \star \star}$ & $4.2 \pm 0.15^{\star \star}$ \\
\hline Group 8 (C-6) & $100 \mathrm{mg} / \mathrm{kg}$ & $1.6 \pm 0.12$ & $2.3 \pm 0.11$ & $2.2 \pm 0.15$ & $2.0 \pm 0.11$ \\
\hline
\end{tabular}

All the data are expressed as mean \pm SEM (standard error of mean); $n=6$ each group; $P$ value $<0.01$ as significant. One-way ANOVA approach followed by Dunnett's multiple comparisons test was employed for the statistical study.

\section{CONCLUSION}

The investigation represented a step towards the drug discovery of some phenoxyacetanilide analogs with better pharmacodynamics and pharmacokinetics attributes. The present study showed the potentials of sixteen acetanilide containing compounds as therapeutically promising anti-inflammatory and analgesic candidates by inhibiting the vital molecular targets such as COX, 15-PGDH, LOX, etc. The study has opened wide avenues for their utilization as future NSAIDs in the treatment of rheumatoid arthritis, autoimmune diseases, etc., but only after thorough clinical screening. The data procured from the sophisticated analytical tools matched exactly with the structural aspects. Maximum COX-2 inhibitory action was observed for C-6 [Methyl 2-(2-oxo-2-(ptolylamino)ethoxy)benzoate] when evaluated by
In vitro cyclooxygenase inhibition activity. This concluded that Compound C6 [Methyl 2-(2-oxo2-(p-tolylamino)ethoxy)benzoate] showed the highest edema reducing potential $(80.12 \%)$, which was quite analogous with the positive control. The molecules C5 [2-phenoxy-N-(o-tolyl)acetamide] exhibited the similar highest analgesic activity which was quite analogous with that of the positive control. The study will definitely inspire medicinal chemists and researchers from allied fields in developing new generations of phenoxyacetanilide based anti-inflammatory and analgesic agents.

\section{ACKNOWLEDGEMENT}

Dr. M.P. Pandey, Honorable Vice Chancellor, IFTM University, Moradabad, assisted the authors in completing this work. The team of authors acknowledges him. This paper is part of a Ph.D. thesis at IFTM University in Moradabad. 


\section{REFERENCES}

1. Medzhitov R. Cell., 2010, 140, 771-776.

2. Ryznerski, Z.; Pol. J. Pharmacol. Pharm., 1980, 32, 403-408.

3. Chen, L.; Deng, H.; Cui, H.; Fang, J.; Zuo, Z.; Deng, J. Oncotarget., 2018, 9(6), 7204-7218.

4. Bua, S.; Di, C.M.L.; Vullo, D.; Ghelardini, C.; Bartolucci, G.; Scozzafava, A.; Supuran, C.T.; Carta, F.; J. Med. Chem., 2017, 60, 1159-1170.

5. Chougala, B.M.; Samundeeswari, S.; Holiyachi, M.; Shastri, L.A.; Dodamani, S.; Jalalpure, S.; Dixit, S.R.; Joshi, S.D.; Sunagar, V.A.; Eur. J. Med. Chem., 2017, 125, 101-116.

6. Pedada, S.R.; Yarla, N.S.; Tambade, P.J.; Dhananjaya, B.L.; Bishayee, A.; Arunasree, K.M.; Philip, G.H.; Dharmapuri, G.; Aliev, G.; Putta, S.; Rangaiah, G.; Eur. J. Med. Chem., 2016, 112, 289-297.

7. Viveka, S.; Shama, P.; Nagaraja, G.K., Ballav, S.; Kerkar, S.; Eur. J. Med. Chem., 2015, 101, 442-451.

8. Li, Y.R.; Li, C.; Liu, J.C.; Guo, M.; Zhang, T.Y.; Sun, L.P.; Zheng, C.J.; Piao, H.R.; Bioorg. Med. Chem. Let., 2015, 25, 5052-5057.

9. Braha, S.; Oniscu, C.; Simionovici, M.; Rev. Med. Chir. Soc. Med. Nat. Iasi., 1985, 89, 316-320.

10. Takeda, Y.; Kawagoe, K.; Yokomizo, A.; Yokomizo, Y.; Hosokami, T.; Shimoto, Y.; Tabuchi, Y.; Ogihara, Y. Chem. Pharm. Bull. (Tokyo)., 1999, 47, 755-961.

11. Sarigol, D.; Uzgoren-Baran, A.; Tel, B.C.; Somuncuoglu, E.I.; Kazkayasi, I.; OzadaliSari, K.; Unsal-Tan, O.; Okay, G.; Ertan, M.; Tozkoparan, B.; Bioorg. Med. Chem., 2015, 23, 2518-2528.

12. Helal, M.H.; El-Awdan, S.A.; Salem, M.A.; Abd-Elaziz, T.A.; Moahamed, Y.A.; El-Sherif, A.A.; Mohamed, G.A.; Spectrochimica. Acta Part A: Mol. Biomol. Spectr., 2015, 135, 764-773.

13. Lee, C. M.; Parks, J. A.; Bunnell, P. R.; Plattner, J. J.; Field, M. J.; Giebisch, G. H.; 1985, 28, 589-594.

14. Lalloyer, F.; Wouters, K.; Baron, M.; Caron, S.; Vallez, E.; Vanhoutte, J.; Baugé, E.; ShiriSverdlov, R.; Hofker, M.; Staels, B.; Tailleux, A.; Arterioscler. Thromb. Vasc. Biol., 2011, 31, 1573-1579.

15. Chłoń-Rzepa, G.; Jankowska, A.; Ślusarczyk, M.; Świerczek, A.; Pociecha, K.; Wyska, E.;
Bucki, A.; Gawalska, A.; Kołaczkowski, M.; Pawłowski, M.; Eur. J. Med. Chem., 2018, 146, 381-394.

16. Golankiewicz, B.; Januszczyk, P.; Ikeda, S.; Balzarini, J.; De Clercq, E.; J. Med. Chem., 1995, 38, 3558-3565.

17. Bertrand, P.; Böhme, G.A.; Durieux, C.; Guyon, C.; Capet, M.; Jeantaud, B.; Boudeau, P.; Ducos, B.; Pendley, C.E.; Martin, G.E.; Eur. J. Pharmacol., 1994, 262, 233-245.

18. Takeda, Y.; Kawagoe, K.; Yokomizo, A.; Yokomizo, Y.; Hosokami, T.; Shimoto, Y.; Tabuchi, Y.; Ogihara, Y.; Otsubo, R.; Honda, Y.; Yokohama, S.; Chem. Pharm. Bull. (Tokyo)., 1998, 46, 951-971.

19. Shimizu, K.; Maruyama, M.; Yasui, Y.; Minegishi, H.; Ban, H.S.; Nakamura, H.; Bioorg. Med. Chem. Lett., 2010, 20, 1453-1456.

20. Hu, C.; Zhou, Z.; Xiang, Y.; Song, X.; Wang, H.; Tao, K.; Ye, X.; Med. Chem. Res., 2018, 27, 194-205.

21. Minegishi, H.; Shinji, F.; Ban, H.S.; Nakamura, H.; ACS Med. Chem. Let., 2013, 4, 297-301.

22. Bonnac, L.; Gao, G.Y.; Chen, L.; Felczak, K.; Bennett, E.M.; Xu, H.; Kim, T.; Liu, N.; Oh, H.; Tonge, P.J.; Pankiewicz, K.W.; Bioorg. Med. Chem. Let., 2007, 17, 4588-4591.

23. Alanazi, A.M.; El-Azab, A.S.; Al-Suwaidan, I.A., ElTahir, K.E.; Asiri, Y.A.; Abdel-Aziz, N.I.; Alaa, A.M.; Eur. J. Med. Chem., 2015, 92, 115-123.

24. Jin, H.; Wei, Z.; Zhi-Ning, H.; Shao-Mei, Y.; Li-Juan, W.; Yu, J.; Zhong-Shi, Z.; Man-Yi, Z.; Ji-Li, J.; Shan-Hua, L.; Fu-Nan. L.; Chem. Biol. Drug Des., 2014, 86, 223-231.

25. Dawood, D.H.; Batran, R.Z.; Farghaly, T.A.; Khedr, M.A.; Abdulla, M.M.; Archiv Der Pharmazie., 2015, 348, 875-888.

26. Abdel-Sayed, M.A.; Bayomi, S.M.; ElSherbeny, M.A.; Abdel-Aziz, N.; Tahir, K.E.; Shehatou, G.S.; Alaa, A.M.; Bioorg. Med. Chem., 2016, 24, 2032-2042.

27. Bukhari, S.N.; Zhang, X.; Jantan, I.; Zhu, H.L.; Amjad, M.W.; Masand, V.H.; Chem. Biol. Drug Des., 2015, 85, 729-742.

28. Grover, J.; Jachak, S.M.; RSC Adv., 2015, 5, 38892-38905.

29. Pereira LC.; Nunes C.; Jamal SK.; Cuccovia IM.; Reis S.; Med Res Rev., 2017, 37, 802-859. 
30. George, M.N.; Horia, P., Constatin, D.; Alexandru-Vasile, M.; Oana, A.; Coman, I.F.; Farmacia., 2010, 58, 2.

31. Bicking, J.B.; Holtz, W.J.; Watson, S.; Cargo, E.; J. Med. Chem., 1976, 19, 530-535.

32. Mahapatra, D.K.; Bharti, S.K.; Asati, V.; Curr. Top. Med. Chem., 2017, 17, 3146-3169.

33. Buckinghaam, J. Dictionary of Organic Compounds, $5^{\text {th }}$ edn, Suppliments 1-4, New York: Champman and Hill., 1892, 198319-86.

34. Weast, R.C. Hand book of Chemistry and Physics, $67^{\text {th }}$ edn, Ed. Florida: CRC Press Inc., 1986-87.

35. Karlgren, M.; Bergstrom, C.A.S. New horizons in predictive drug metabolism and pharmacokinetics., 2015, 49, 1-26.

36. Shukla, A.K.; Srivastava, A.K.; Intern. J. Med.
Res. \& Rev., 2015, 3(11), 1311-1316.

37. Rosa, M.D.; Papadimitriou, J.M.; Willoughby, D. A.; J. Pathology., 1971, 105, 239-256.

38. Rakesh, K.P.; Manukumar, H.M.; Gowda, D.C.; Bioorg. Med. Chem. Lett., 2015, 25, $1072-1077$.

39. Woolfe, G.; Me Donald, A.D. J. Pharmacol. Exper. Ther., 1944, 80, 300.

40. Ananthanarayan, R.; Panikar, C.K.J. Text Book of Microbiology, $7^{\text {th }}$ edn. Orient Longman Publication, Hyderabad., 2005, 34-38.

41. McNally, V.A.; Rajabi, M.; Gbaj, A.; J. Pharm. Pharmacol., 2007, 59, 537-547.

42. Pagadala, N.S.; Syed, K.; Tuszynski, J.; Biophys. Rev., 2017, 9, 91-102.

43. Lipinski, C.A.; Lombardo, F.; Dominy, B.W.; Feeney, P.J.; Adv. Drug Delivery Rev., 1997, 23, 3-25. 